\title{
Structural Bioinformatics of Protein \& DNA, as Early Stimulation in Basic Education of Rural and Indigenous Communities of Oaxaca
}

\author{
Susana Lozano-Muniz ${ }^{1,2}$, Maria del Carmen Urzua-Hernandez ${ }^{2,3}$ \\ ${ }^{1}$ Biotechnology Institute, Universidad del Papaloapan, Tuxtepec, Mexico \\ ${ }^{2}$ International Foundation for Biotechnology Research \& Early Stimulation in the Culture of Health, \\ Nutrition, Sport, Art, Science, Technology \& Society A.C., San Juan Bautista Tuxtepec, Mexico \\ ${ }^{3}$ Facultad de Quimica, Universidad Nacional Autonoma de Mexico, Ciudad de México, Mexico \\ Email: susana_lozano@hotmail.com
}

Received June 2013

\begin{abstract}
As stated in the Declaration of the Rights of the Child, children have the right to go to school for free, to play, and to have the same opportunity to develop and to learn to be responsible and useful [1]. Young children are curious by nature and they have passion for learning [2]. An environment that encourages scientific thinking is what gives young children the time, space and materials to exercise their curiosity [3]. The aim of this paper is to present a methodology for the development of educational environments based on digital technology, internet and free programs available on the web, for the use and application of structural bioinformatics protein and DNA, for early stimulation in basic education at rural and indigenous communities in state of Oaxaca, conducted in On Line Learning \& Training "OLL \& T". The course is divided into 4 sections: 1) Introduction to the topic of protein and DNA structure; 2) Search in protein data bank; 3) Download RasTop program and use it as bioinformatics tool; 4) Emulation of building a viral molecule. Workshops were given to children in elementary, middle and high school at the Universidad Del Papaloapan during the National Week of Science and Technology, every year in Oaxaca since 2007 to 2012 and in Monterrey 2010 at the Universidad Autonoma de Nuevo León. Conclusions: positive impact was achieved in basic education in the area of natural sciences by analyzing the molecular basis of protein and deoxyribonucleic acid, theoretically and practically, as a support for teachers.
\end{abstract}

Keywords: TICs; Childhood; Improvement; Achievement

\section{Introduction}

Mexico has important advances in the education system, by the annual implementation of the test called The National Assessment of Academic Achievement in Schools test (for its acronym in Spanish ENLACE). This test recognizes work strategies that allow the child to have better (intellectual, social and physical ability). For example, nowadays, the use of the computer as a basic tool from an early age begins to stimulate the child's mind as it activates his imagination and attention span; for this reason it is important to basically outline the material resources available to the School. Activities that can be made through the Information \& Communication Technology (TICs) in education are, in general, motivating to the students for their interactivity, by the use of visuals, colors and three dimensional figures and hearing, among other advantages. We used National Institute of Statistics, Geography and Informatics for its acronym in Spanish
(INEGI) data to make a situation analysis of social, educational and technology issues available on the Mexican population [4]. The consensus of population and housing unit of measurement for thousands of inhabitants in 2010 registered a value of 112,337 [5].

Child Population: According INEGI [6] the percentage of the population aged 0 to 14 years in 1940 Tabasco is the entity that registered the highest value with $48.6 \%$ of its population in this age range, while the record of Federal District is 34.5\%, lower with all entities in an increasing trend was observed up to 1970 years, in which the maximum value in all of them emphasizing Tabasco, Zacatecas and the highest values of 50.6 and $49.7 \%$ respectively.

\subsection{Infant Mortality}

To compare the states for 1990 the mortality rate and percentage of population in rural areas, considering these 
as less than 2500 inhabitants, there is a direct relationship between both indicators to percentile higher rates of rural population are more higher, infant mortality being greater the difference in extreme values of each of these indicators, to display the changing values in the entities we see a general decrease in mortality of children under one year or less marked decreases in the percentage rural population since the 1990-2005 period [7].

\subsection{Educational Backwardness and Rural Locations}

The percentage of women over 14 who have not completed the 9 grades of compulsory basic education is expressed and localized mainly in the states with the highest proportion of people in rural areas. In recent decades the gradual depletion of the educational lag kept a close relation to the decline in mortality rates of children under one year.

The schooling offers women a new larger social network, reference groups and greater identification with the modern world of health institutions, educational gap reduction between women could be related to an increased interest in health services. That is possible with greater approval preventive behaviors and new remedies which contribute to increased survival of less than one year. Reducing the educational gap between women could be related to an increased interest in health services, allowing greater approval of preventive behaviors and new medicines also contributing to increased survival of children less than one year [8].

\section{Material and Methodology.}

The course is divided into 4 sections:

\subsection{Introduction to the Topic of Protein and DNA Structure}

1) The first questions the teacher asks the students are: If the student heard about proteins? Which proteins they know? Which Food has proteins? Why they believe the human body requires protein? What happens when proteins are ingested? Why it is necessary to take in food? After analyzing the questions and possible answers, (is introduced to the subject of the proteins by PowerPoint presentation and bibliographic search in information networks. The subject of the proteins by PowerPoint presentation and bibliographic search in information networks are introduced.)

2) They are taught by figures such as this formed the primary, secondary, tertiary (is at this time which explains the issue of DNA) and quaternary structure. For example, what is a linear sequence of aa, an alpha helix, a beta folded parallel, one anti-parallel beta-sheet, a bar- rel, a sequence of folded beta/alpha-beta helix folded alpha helix sequence/corner/alpha helix, one beta sequence folded/corner/alpha helix-beta-sheet, beta barrels a sequence, a sequence of alpha helices, beta pleated sequence, a sequence of alpha helices/beta fold, are shown examples of quaternary structure of proteins, viral capsid, membrane proteins, the relationship in size from water molecules, aa, proteins, deoxyribonucleic acid (DNA), alpha helices, enzymes, antibodies, viruses, bacteria, globule red and white blood cell. Teacher explains that although proteins appear differently represented, they are the same protein, or it can be similar, then the students see the proteins in structure of bones, ribbons, spheres (balls), globular, etc. After that continues with the following objectives of the workshop [9].

\subsection{Search in Protein Data Bank}

The Protein Data Bank (PDB) is one of the most useful bioinformatics resources, this contains almost 84.966 three-dimensional structures of proteins. It is important to note that each of these files contains the coordinates in the space of all atoms in the protein (excluding hydrogens in many cases). If we consider that a protein has many tens or even hundreds of waste, and that each of them has about 10 atoms, how many numerical data are required to form one of these files? Access is http://www.pdb.org and each file has a four-character identifier, often a number followed by three letters. The teacher taught the children to access this bioinformatics tool to search for proteins, to view them on line in Jmo online, download protein information, and change the display of this protein in various forms of representation in Jmol online [10].

\subsection{Download RasTop Program \& Use It as Bioinformatics Tool}

RasTop is a program that unlike Jmol, KING, and WebMol, requires downloading and installing before use. The current version is 2.2 and you can get it for free at http://www.geneinfinity.org/rastop/. RasTop is the heir of a previous program called RasMol, can still be found at http://www.openrasmol.org/. In our course, the students are taught how to download and install the program. Either way the program was previously installed, the students seek the appropriate icon and open the sequences downloaded from the PDB in order to read the structure, for this select File / Open and select the PDB structure files are available and explore the different menus and buttons [11].

\subsection{Emulation of Building a Viral Molecule}

The students printed an icosahedron, cut it and pasted the folds forming a three-dimensional structural protein of a 
virus, after analyzing the viral structural protein PDB [12].

\section{Results}

Workshops were given to children in elementary, middle and high school at the University of Papaloapan in Tuxtepec Oaxaca during the National Week of Science and Technology, every year since 2007-2012 and in UANL in Monterrey on 2010.

\section{Discussions}

As stated in the Declaration of the Rights of the Child, children have the right to go to school for free, to play, and to have the same opportunity to develop and to learn to be responsible and useful. Infant mortality is relevantly as an indicator of parental education levels, which has relation with the lack of health prevention measures, and /or they can't have a good job or to pay for health resources, and in a rural places, they usually don't have appropriate health systems, so with this kind of work, we try to support basic education in rural and indigenous areas. Using this methodology in Early Learning in Science and Technology, we will be able to stimulate and intervene in the evolutionary development of children enrolled in primary education, promote the scientific development within the natural sciences area, positively impact their curiosity to learn and to use the Internet tool available online. Basic educational teachers who accompany their students are impressed by that information available online. They taught both teachers and students to visit the websites of protein databases. The workshop is offered to students from rural and indigenous communities in Oaxaca Tuxtepec, since 2007 to 2012 as in a cosmopolitan city like Monterrey in 2010, during the National Week of Science and Technology and observe the following: that when students come from rural and indigenous communities are interested to learn about computer use as an innovation, and they are alert and focus at class, because the teachers have indoctrinated them to pay attention to instructor of the workshop, or do not have access to this technological tool or as a teacher usually do not know how to use it. In a city like Monterrey, they have frequent access to these tools whether at home, school or cyber. It was also observed that these pupils from cosmopolitan cities, have two possibilities, one of which is familiarity with technological tools are more knowledgeable and question incurred with respect to the information provided in the workshop so that one has to constantly prepare in the field to respond to these questions or otherwise students may be constantly distracted, changed the screen saver to turn the computer on, or some other settings the same as the wallpaper, font, color, etc., during the time that the instructor tries to give his workshop, that is, the slightest slip of the instructor students are distracted doing what they most like to do on your computer, and even trying to access your email account, chat or social network.

\section{Conclusion}

Early stimulation is a set of actions to promote the physical, mental and social aspects of any child, and even helps to prevent child psychomotor retardation, cures and rehabilitates motor impairment, sensory deficits, intellectual disabilities, and language disorders. This supports the integration of these children to society, replacing the burden of feeling useless for the joy of becoming a useful individual and reducing the feeling of aggression, indifference or rejection, and stimulating solidarity, cooperation and hope. Educational backwardness and poverty are the main factors that exist in the rural states, which affect the child population, and lead to a high index of infant mortality, relevant as an indicator of parental education levels, which have relation to the lack of health prevention measures, and /or they can't have a good job to pay for health resources, and in a rural places, they usually don't have appropriate health systems, so with this kind of work we try to support basic education in rural and indigenous areas..

\section{Acknowledgements}

We thank to CONACYT SEP SEB project No. 81936 and the support from International Foundation for Biotechnology Research \& Early Stimulation in the Culture of Health, Nutrition, Sport, Art, Science, Technology \& Society A.C.

\section{REFERENCES}

[1] Declaration of the Rights of the Child. http://www.un.org/cyberschoolbus/humanrights/resources /plainchild.asp

[2] J. Raffini, "Winners without Losers: Structures and Strategies for Increasing Students' Motivation to Learn,” Allyn and Bacon, Boston, 1993, 286 Pages. http://www.kidsource.com/kidsource/content2/student_m otivatation.html

[3] R. A. Wilson, "The Wonders of Nature: Honoring Children's Ways of Knowing. Early Childhood News,” Early Childhood Environmental Education, 2013. http://projectwet.org/project-wet-news-events/blog_entry/ early-childhood-environmental-education/

[4] Y. Reyes-Vidal, M. Ortiz, F. Perez, F. Garza, G. Nunez, M. C. Urzua and S. Lozano, "Early Stimulation on Science and Technology in Elementary School,” In: F. Fernandez-Luqueno, F. Lopez-Valdez and S. Lozano-Muniz, Eds., Biotechnology Summit, 2012, pp. 239-244. http://www.bio.edu.mx/imagenes/Biotechnology_Summit 2012.pdf 
[5] INEGI, “Poblacion, Hogares y Vivienda,” 2013. http://www3.inegi.org.mx/Sistemas/temasV2/Default.asp $\mathrm{x}$ ?s=est\&c $=17484$

[6] INEGI, "Poblacion Infantile,” 2013. http://www.youtube.com/watch?v=KDs2QHbkg64

[7] INEGI, “Mortalidad Infantil y Localidades Rurales,” 2013. http://www.youtube.com/watch?v=IbSaAqrqk-A

[8] NEGI, “Rezago Educativo y Localidades Rurales,” 2013. http://www.youtube.com/watch?v=RntBb2m-Tks\&f

[9] "Introduction to the Topic of Protein and DNA Structure".
https://www.facebook.com/\#!/InternatFound4BiotechRes earchEarlyStimlatScTech-

Soc/media_set?set $=$ a.10152088611095327.914308.74845 0326\&type $=3$

[10] Protein Data Bank. http://www.pdb.org/

[11] Rastop. http://www.geneinfinity.org/rastop/

[12] Icosaedro.

https://www.facebook.com/photo.php?fbid=10152088737 985327\&set=a.10152088611095327.914308.748450326 \&type $=3 \&$ theater 